\title{
Solid Solutions in Aluminum Electrolytes with the Participation of LiF
}

\author{
Yulia N. Zaitseva*a, Sergei D. Kirik ${ }^{\text {a, b, }}$ \\ Aleksandr S. Samoilob ${ }^{b}$ Petr S. Dubinin ${ }^{b}$, \\ Oksana E. Bezrukova ${ }^{b}$, Aleksandr N. Zalogab, \\ Sergei G. Ruzhnikov ${ }^{\mathbf{b}}$ and Igor S. Yakimov ${ }^{\mathrm{b}}$ \\ anstitute of Chemistry and Chemical Technology \\ FRC «Krasnoyarsk Scientific Center of the SB RAS» \\ Krasnoyarsk, Russian Federation \\ ${ }^{b}$ Siberian Federal University \\ Krasnoyarsk, Russian Federation
}

Received 21.09.2021, received in revised form 15.11.2021, accepted 13.01.2022

\begin{abstract}
The paper presents the investigation of the solid solutions formation in the fluoride system $\mathrm{Na}_{5} \mathrm{Al}_{3} \mathrm{~F}_{14}-\mathrm{Na}_{3} \mathrm{AlF}_{6}-\mathrm{K}_{3} \mathrm{AlF}_{6}$ with the addition of LiF. Two local regions were under consideration. The first case concerns the possibility of potassium and sodium cations replacing with lithium in the elpasolite $\left(\mathrm{K}_{2} \mathrm{NaAlF}_{6}\right)$ when $\mathrm{LiF}$ is added to the electrolyte. In the second, the effect of lithium fluoride on the chiolite $\left(\mathrm{Na}_{5} \mathrm{Al}_{3} \mathrm{~F}_{14}\right)$ was studied. The investigation was motivated by the need to control the composition of the electrolyte during the electrolytic production of aluminum. The electrolyte samples were obtained from the initial fluorides under laboratory conditions. Determination of crystal-chemical details of the structure of solid solutions was carried out by the method of full-profile analysis (Rietveld method) on multiphase polycrystalline samples. It was found that the addition of $\mathrm{LiF}$ in the structure of elpasolite is accompanied by a gradual substitution of lithium for sodium with the formation, ultimately, of the $\mathrm{K}_{2} \mathrm{LiAlF}_{6}$ phase with the lattice parameter $\mathrm{a}=8.0779 \AA$. Potassium is not subject to substitution. No dissolution of $\mathrm{LiF}$ in the structure of cryolite $\left(\mathrm{Na}_{3} \mathrm{AlF}_{6}\right)$ was found. It was shown that chiolite does not form solid solutions with $\mathrm{LiF}$ upon crystallization.
\end{abstract}

Keywords: system $\mathrm{Na}_{3} \mathrm{AlF}_{6}-\mathrm{K}_{3} \mathrm{AlF}_{6}-\mathrm{AlF}_{3}-\mathrm{LiF}$, electrolyte for aluminium production, solid solutions, $\mathrm{X}$-ray powder diffraction.

(C) Siberian Federal University. All rights reserved

This work is licensed under a Creative Commons Attribution-NonCommercial 4.0 International License (CC BY-NC 4.0).

* Corresponding author E-mail address: j-n-zaitseva@yandex.ru 


\title{
Твердые растворы в алюминиевых электролитах с участием LiF
}

\author{
Ю. Н. Зайцева ${ }^{a}$, С.Д. Кирик ${ }^{a, \sigma}$, \\ А.С. Самойло ${ }^{\sigma}$, П.С. Дубинин ${ }^{\sigma}$, О.Е. Безрукова ${ }^{\tilde{\sigma}}$, \\ А.Н. Залога ${ }^{\tilde{\sigma}}$ С. Г. Ружников ${ }^{\tilde{0}}$, И.С. Якимов ${ }^{\sigma}$ \\ ${ }^{a}$ Институт химии и химической технологии СО РАН \\ обособленное подразделение ФИЦ КНЦ СО РАН \\ Российская Федерачия, Красноярск \\ ${ }^{6}$ Сибирский федеральный университет \\ Российская Федерачия, Красноярск
}

\begin{abstract}
Аннотация. Представлены исследования образования твердых растворов в двух локальных областях системы $\mathrm{Na}_{5} \mathrm{Al}_{3} \mathrm{~F}_{14}-\mathrm{Na}_{3} \mathrm{AlF}_{6}-\mathrm{K}_{3} \mathrm{AlF}_{6}$ с добавлением LiF. В первом случае рассмотрена возможность замещения катионов калия и натрия в эльпасолите $\left(\mathrm{K}_{2} \mathrm{NaAlF}_{6}\right)$ на литий при добавлении в электролит LiF. Во втором изучено влияние фторида лития на хиолит $\left(\mathrm{Na}_{5} \mathrm{Al}_{3} \mathrm{~F}_{14}\right)$. Изучение фторидной системы обосновано необходимостью контроля состава электролита при электролизе алюминия. Исследования были выполнены на образцах, полученных из исходных фторидов в лабораторных условиях. Определение кристаллохимических деталей строения твердых растворов проведено методом полнопрофильного анализа (метод Ритвельда) на многофазных поликристаллических образцах.

Установлено, что при добавлении LiF в структуре эльпасолита происходит постепенное замещение натрия на литий с образованием в конечном счете фазы $\mathrm{K}_{2} \mathrm{LiAlF}_{6}$ с параметром решетки $\mathrm{a}=8,0779 \AA$ А. Калий не подвергается замещению. Растворения $\mathrm{LiF}$ в структуре криолита $\left(\mathrm{Na}_{3} \mathrm{AlF}_{6}\right)$ не обнаружено. Показано, что хиолит при кристаллизации не образует твердых растворов с LiF.
\end{abstract}

Ключевые слова: система $\mathrm{Na}_{3} \mathrm{AlF}_{6}-\mathrm{K}_{3} \mathrm{AlF}_{6}-\mathrm{AlF}_{3}-\mathrm{LiF}$, электролиты для производства алюминия, твердые растворы, порошковая рентгеновская дифракция.

Цитирование: Зайцева, Ю.Н. Твердые растворы в алюминиевых электролитах с участием LiF / Ю. Н. Зайцева, С.Д. Кирик, А. С. Самойло и др. // Журн. Сиб. федер. унта. Химия, 2022, 15(1). С. 22-31. DOI: 10.17516/1998-2836-0268

\section{Introduction}

The Heroult-Hall electrolytic process [1, 2], used for the industrial production of primary aluminum, is possible due to the dissolution of alumina in a fluoride-salt melt at a temperature of about $960{ }^{\circ} \mathrm{C}$. For more than 100 years, the compositions of the electrolytes used have been invariably based on the (NaF- 
$\left.\mathrm{AlF}_{3}\right)$ system in the crystallization area of cryolite $\left(\mathrm{Na}_{3} \mathrm{AlF}_{6}\right)$ and chiolite $\left(\mathrm{Na}_{5} \mathrm{Al}_{3} \mathrm{~F}_{14}\right)$. Improvement and optimization of electrolyte properties is carried out through the addition of various fluoride salts: $\mathrm{CaF}_{2}, \mathrm{MgF}_{2}, \mathrm{BaF}_{2}, \mathrm{KF}, \mathrm{LiF}[3,4]$. Some fluorides, such as lithium and potassium, can enter the bath with alumina $[5,6]$. In the last decade, there has been an increase in the number of publications devoted to a detailed study of potassium-containing electrolyte [7-11]. For the efficiency of the electrolytic process, the composition of the multicomponent melt requires rather fine control. Practice shows that the most objective and accurate analysis of the electrolyte can be obtained on cooled samples [12]. It is possible that this is one of the most motivating factors for a thorough study of the subsolidus region of multicomponent diagrams of the type $\left(\mathrm{AlF}_{3}-\mathrm{NaF}-\mathrm{Me}_{1} \mathrm{~F}_{\mathrm{i}}-\mathrm{Me}_{2} \mathrm{~F}_{\mathrm{j}} \ldots\right)$.

Solid solutions are common in fluoride salt systems. Craig, D. F. and Brown, J. J. [13], describing the equilibria in the $\mathrm{CaF}_{2}-\mathrm{AlF}_{3}-\mathrm{Na}_{3} \mathrm{AlF}_{6}$ system, have indicated the presence of $\beta$-cryolite-based solid solutions along the $\mathrm{Na}_{3} \mathrm{AlF}_{6}-\mathrm{NaCaAlF}_{6}$ quasi-binary section. The homogeneity region of the solid solution increased with temperature. Later, these data were confirmed by considering the quasi-binary section $\mathrm{CaF}_{2}-\mathrm{Na}_{3} \mathrm{AlF}_{6}[14]$.

According to [15], there were formed two regions of solid solutions in the $\mathrm{Na}_{3} \mathrm{AlF}_{6}-\mathrm{Li}_{3} \mathrm{AlF}_{6}$ system in the temperature range $540-720{ }^{\circ} \mathrm{C}$. They were both on the basis of $\mathrm{Na}_{3} \mathrm{AlF}_{6}$ and $\mathrm{Li}_{3} \mathrm{AlF}_{6}$. Below a temperature of $540{ }^{\circ} \mathrm{C}$, they decomposed into two compounds of constant composition $\mathrm{Na}_{3} \mathrm{AlF}_{6}$ and $\mathrm{LiNa}_{2} \mathrm{AlF}_{6}$. The formation of a solid solution region based on $\mathrm{Na}_{3} \mathrm{AlF}_{6}$ was described in [16].

There was reported in the paper [17], that the binary section $\mathrm{Na}_{3} \mathrm{AlF}_{6}-\mathrm{K}_{3} \mathrm{AlF}_{6}$ was divided into two subsystems by elpasolite $\left(\mathrm{K}_{2} \mathrm{NaAlF}_{6}\right)$ with a melting point of $954{ }^{\circ} \mathrm{C}$. Above the line of polymorphic transformation of cryolite $\left(542{ }^{\circ} \mathrm{C}\right)$, there were regions of solid solutions based on $\mathrm{K}_{2} \mathrm{NaAlF}_{6}$ and the high-temperature form of $\mathrm{Na}_{3} \mathrm{AlF}_{6}$. The polymorphic transition temperature decreased to $340{ }^{\circ} \mathrm{C}$ at the composition shifted towards $\mathrm{K}_{2} \mathrm{NaAlF}_{6}$. The mixture of two individual phases $\mathrm{Na}_{3} \mathrm{AlF}_{6}$ and $\mathrm{K}_{2} \mathrm{NaAlF}_{6}$ was observed at room temperature.

The study of the NaF-KF-AlF 3 system in $[18,19]$ have shown small region of solid solutions based on $\mathrm{Na}_{5} \mathrm{Al}_{3} \mathrm{~F}_{14}$. Potassium ions replaced sodium only in one of two crystallographic positions.

There were many studies, where only references or suspicions about the existence of solid solutions were formulated. Comprehensive studies have not been undertaken. The presence of solid solutions was often hidden by the temperature dependence and the width of the region of existence. As the result there were no detailed descriptions of the solid solutions compositions. At the same time, detailed information on the subsolidus area is important for solving applied problems. Data on the composition of phases, including phases with a variable composition, are used to provide X-ray diffraction analysis of the electrolyte composition during technological control [12]. Sampling for analysis is carried out directly from the operating electrolysis bath at a high temperature. The sample cooling mode is practically not controlled. It is obvious that the composition of the solid solution can vary.

This work presents the results of investigation of the solid solution formation in two local regions of $\mathrm{Na}_{5} \mathrm{Al}_{3} \mathrm{~F}_{14}-\mathrm{Na}_{3} \mathrm{AlF}_{6}-\mathrm{K}_{3} \mathrm{AlF}_{6}$ system when $\mathrm{LiF}$ was added to the electrolyte. Research topics arose directly from the industrial practice of the electrolyte control by quantitative X-ray diffraction analysis. The first topic is related to the possibility of potassium and sodium cations in the elpasolite to be replaced with lithium when $\mathrm{LiF}$ have been added to the electrolyte. In the second topic, the effect of lithium fluoride on chiolite is discussed. Earlier it was found $[18,19]$ that chiolite forms solid solutions with the substitution of sodium for potassium. There was no information on the change in chiolite in 
the presence of LiF. The studies were carried out on samples obtained from the initial fluorides under laboratory conditions. Determination of crystal-chemical details of the structure of solid solutions was carried out by the method of full-profile analysis (Rietveld method) on multiphase polycrystalline samples.

\section{Experimental}

Sample preparation. Initial substances $\mathrm{NaF}, \mathrm{AlF}_{3}, \mathrm{KF}, \mathrm{LiF}$ of reagent grade were used for the synthesis of samples. Before synthesis, all the starting materials were calcined in a furnace at a temperature of $400-450{ }^{\circ} \mathrm{C}$ for at least 1 hour. Stoichiometric weighed portions of $\mathrm{NaF}, \mathrm{AlF}_{3}, \mathrm{KF}, \mathrm{LiF}$ were ground in an agate mortar, placed in the closed platinum crucible in the furnace at appropriate temperatures and kept in the furnace for 30-50 min. before melting. Crystallization of the melts was carried out by pouring the melt from the crucible into a massive metal cooled mold. The weight of the samples was about $3 \mathrm{~g}$. After complete cooling, the sample was removed and ground in an agate mortar. Then, to achieve an equilibrium state, each sample was thermally treated at different temperatures. The obtained materials were analyzed by X-Ray diffraction control at all stages of preparation. Weight loss during heat treatment was in the range of $1.3-1.8 \mathrm{wt} . \%$.

$X$-ray diffraction (XRD). X-ray powder diffraction data were obtained using $\mathrm{CuK} \alpha$ radiation on an X'Pert PRO diffractometer with a PIXcel detector equipped with a graphite monochromator (PANalytical). The samples were ground in an agate mortar and prepared by direct filling of the cuvette. Scans were carried out at room temperature in the range from 5 to $80^{\circ}$ on the $2 \theta$ scale, with a step of $0.026^{\circ}, \Delta \mathrm{t}-50 \mathrm{~s} / \mathrm{step}$.

$X$-ray diffraction data processing. The crystal structures were refined from powder diffraction data by full-profile analysis (Rietveld method) using the FulProf program [20] in the multiphase sample mode. The coordinates and the occupancies of atomic positions were refined. The thermal parameters of the atoms were refined in the isotropic approximation.

\section{Results and discussion}

\section{Formation of solid solutions in the $\mathrm{Na}_{3} \mathrm{AlF}_{6}-$}

$\mathrm{K}_{2} \mathrm{NaAlF}_{6}$ system upon doping with LiF.

The presence of cryolite is the feature of electrolytes containing elpasolite after crystallization. This is consistent with the data obtained by of thermal analysis [17], where a continuous region of solid solutions were established above $500{ }^{\circ} \mathrm{C}$. The solid solution decomposed into cryolite and elpasolite below the indicated temperature.

The observed transformations can be considered from a crystal-chemistry point of view. There two layers can be distinguished in the crystal structure of cryolite (Fig. 1a). The first is a mixed cationanionic layer and the second is a cationic one. Sodium cations in the first anionic layer (position $2 b$ ) have a distorted octahedral environment with Na-F distances in the range of 2.227-2.282 A. Sodium atoms (position 4e) in the second cationic layer, have a tetrahedral environment with $\mathrm{Na}-\mathrm{F}$ distances in the range of 2.29-2.35 A. From the point of view of the interatomic distances it seems unlikely to expect the substitution of potassium for sodium in the indicated positions.

There is a characteristic detail of the low-temperature cryolite structure. The axis of $\mathrm{AlF}_{6}$ octahedron is inclined to the vertical unit cell axis (c) at the angle is $19.7^{\circ}$. As the temperature rises, the 


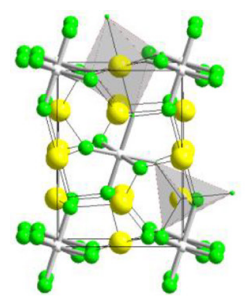

a

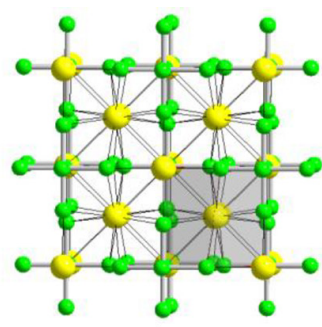

$\mathrm{b}$

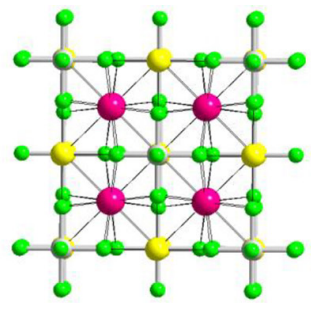

c

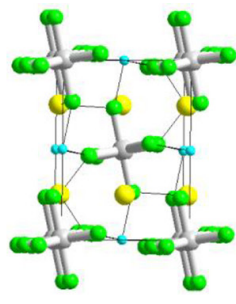

d

Fig. 1. Crystal structures: (a) - low-temperature form of cryolite (alpha-Na $\mathrm{AlF}_{6}$ ), (b) - high-temperature form of cryolite (beta- $\mathrm{Na}_{3} \mathrm{AlF}_{6}$ ), (c) elpasolite $\mathrm{K}_{2} \mathrm{NaAlF}_{6}$, (d) $\mathrm{LiNa}_{2} \mathrm{AlF}_{6}$

axes of the octahedron are oriented along the axes of the cell. Above $500{ }^{\circ} \mathrm{C}$, the octahedron axis has a vertical direction. The transition to the high-temperature $\beta$-form is carried out in a continuous manner. The symmetry group of the $\mathrm{P} 2{ }_{1} / \mathrm{n}$ changes to Fm $3 \mathrm{~m}$ (Fig. 1b). The nearest environment of sodium in position $4 \mathrm{a}$ forms an octahedron with Na-F distances of $2.283 \AA$. The environment of the sodium $8 \mathrm{c}$ position from a tetrahedron is transformed into a cuboctahedron with Na-F distances of $2.85 \AA$. The resulting structure repeats the structure of elpasolite (Fig. 1c). The dimensions of the cationic cavities are prone to isomorphic substitution of sodium for potassium. It explains the formation of a continuous region of solid solutions.

The crystal structure of $\mathrm{LiNa}_{2} \mathrm{AlF}_{6}$ (Fig. 2d) repeats the structure of the low-temperature cryolite with a slight displacement of the second cationic layer, in which sodium is located. The similarity of the structures encourages the expectation of a possible mixing of $\mathrm{LiNa}_{2} \mathrm{AlF}_{6}$ with the structure of elpasolite at high temperatures.

In this work, attention was paid to the changes in the crystal structure of cryolite and elpasolite at high temperatures which could happened in a result of the subsequent addition of 5, 10, 15, 20, $25 \mathrm{wt} . \%$ $\mathrm{LiF}$ to the electrolyte sample. The study was carried out on a series of samples lying on the $\mathrm{Na}_{3} \mathrm{AlF}_{6}-$ $\mathrm{K}_{2} \mathrm{NaAlF}_{6}$, annealed at $750{ }^{\circ} \mathrm{C}$ and at $450^{\circ} \mathrm{C}$.

The Figure 2 shows $\mathrm{X}$-ray diffraction patterns of samples with the composition $\mathrm{Na}_{3} \mathrm{AlF}_{6} / \mathrm{K}_{2} \mathrm{NaAlF}_{6}=$ $=60 / 40$. After annealing at $750{ }^{\circ} \mathrm{C}$, a cubic elpasolite phase with the unit cell parameter of $8.015 \AA$ was dominated. The right-sided shoulders in diffraction lines (Fig.2) can be associated with the formation of a small amount of cryolite, as a result of the partial decomposition of the solid solution during the quenching of the sample. The X-ray diffraction pattern shows well-crystallized phases of elpasolite and cryolite after annealing the sample at $450{ }^{\circ} \mathrm{C}$. The lattice parameter of elpasolite essentially increases to $8.086 \AA$. However it is slightly lower than that of the stoichiometric phase ( $8.118 \AA)$. Refinement of the occupancy of the eight-fold cationic position leads to the composition $7.46 \mathrm{~K}+0.54 \mathrm{Na}$.

After annealing at $750{ }^{\circ} \mathrm{C}$ elpasolite shown a tendency to increase the lattice parameter in the range of 7.990-8.098 $\AA$ upon transition in composition from $\mathrm{Na}_{3} \mathrm{AlF}_{6}$ to $\mathrm{K}_{2} \mathrm{NaAlF}_{6}$. Annealing at $450{ }^{\circ} \mathrm{C}$ gave the change in the lattice parameter in a narrow range of $8.0840-8.098 \AA$, which indicated the absence of a continuous region of solid solutions at this temperature. Potassium in the eight-fold cationic position was substituted for sodium by only $6 \%$, which was $\sim 2 \%$ in the structure as a whole. Repetition of this value for other samples indicated the limiting composition of the solid solution. The cryolite unit cell parameters were close to the parameters of a standard cryolite sample [21]. Refinement 


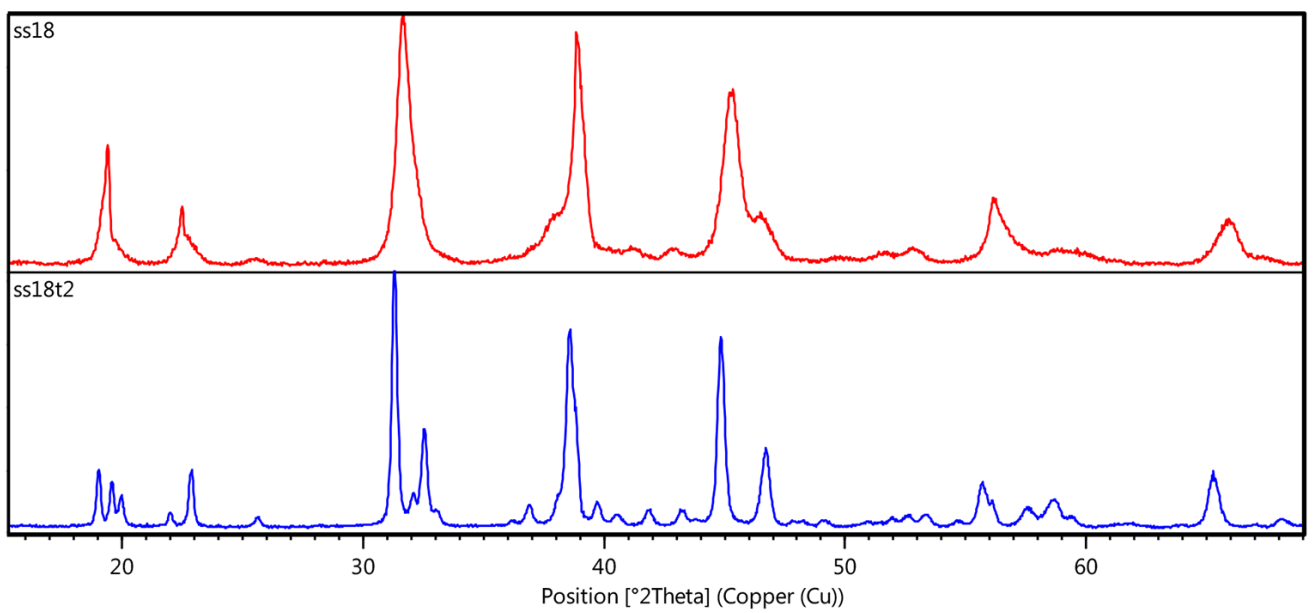

Fig. 2. X-ray diffraction patterns of the sample with composition $\mathrm{Na}_{3} \mathrm{AlF}_{6} / \mathrm{K}_{2} \mathrm{NaAlF}_{6}=60 / 40$ at $450{ }^{\circ} \mathrm{C}$ (lower) and $750{ }^{\circ} \mathrm{C}$ (upper)

of the cryolite structure did not reveal changes in the occupancy of cation positions for all samples. The observed insignificant changes in the unit cell parameters, within $\pm 0.02 \AA$, should be attributed to a change in the rotation of the $\mathrm{AlF}_{6}$ octahedron. Above $500{ }^{\circ} \mathrm{C}$, the cryolite structure turned out to be adapted to replace potassium ions in sodium positions. As a result the wide area of a solid solution was formed. At cooling, the solid solution area shrunk. Cryolite did not support the structure of elpasolite without significant substitution of sodium for potassium. Because cryolite structure was rearranged into a low-temperature form.

When LiF was added to elpasolite, there was observed a small regular shift of all lines on the $\mathrm{X}$-ray powder diffraction pattern to the far region with some change in intensity. With an increase in the addition of $\mathrm{LiF}$, small lines related to $\mathrm{NaF}$ appeared on the X-ray diffraction patterns. It was difficult to judge about the presence of $\mathrm{LiF}$, since the positions of the $\mathrm{LiF}$ lines were overlapped by the elpasolite lines. In the considered limit of concentration changes, the appearance of new multicomponent phases does not occur. Refinement of the lattice parameters was carried out by the method of full-profile fitting of X-ray diffraction patterns (LeBail method). Table 1 and the graph in Fig. 3 show the refined lattice parameters.

Table 1. Lattice parameters of the main phase in the samples of the series $\mathrm{K}_{2} \mathrm{NaAlF}_{6}+0,5,10,15,20,25 \mathrm{wt} \% \mathrm{LiF}$

\begin{tabular}{|c|c|}
\hline LiF, wt., $\%$ & Unit cell parameter a, $\mathcal{A}$ \\
\hline 0 & 8.1179 \\
\hline 5 & 8.1057 \\
\hline 10 & 8.0934 \\
\hline 15 & 8.0841 \\
\hline 20 & 8.0794 \\
\hline 25 & 8.0779 \\
\hline
\end{tabular}




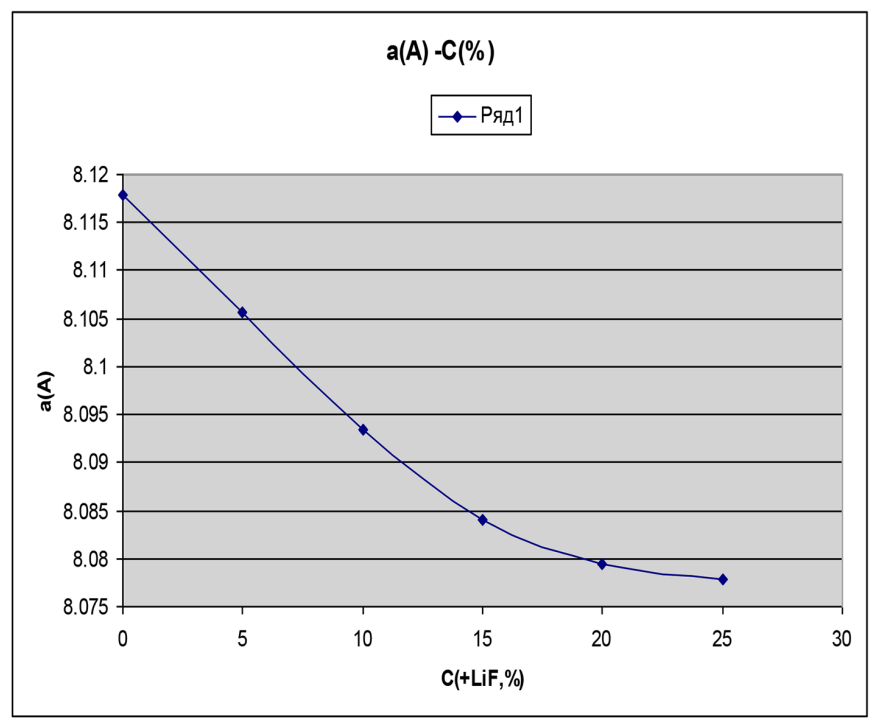

Fig. 3. Graph of changes in the lattice parameter of elpasolite versus the concentration of LiF additive

The lattice parameter decreases with an increased with the amount of lithium fluoride. Two zones could be distinguished on the graph. The first zone with a LiF contented of up to $12-15 \mathrm{wt} . \%$ represented a linear decrease in the lattice parameter. The boundaries of the zone corresponded to the complete substitution of lithium for sodium: $\mathrm{K}_{2} \mathrm{NaAlF}_{6} \rightarrow \mathrm{K}_{2} \mathrm{LiAlF}_{6}$. The second zone was flat and indicated the completion of the replacement process. It can be concluded that elpasolite interacts with $\mathrm{LiF}$ with the substitution of lithium for sodium. The depth of substitution corresponds to one sodium atom, that is, no further substitution is observed.

Thus, the composition of a multiphase mixture with the participation of cryolite and elpasolite upon heating obeys the following regularities. At temperatures below $500^{\circ} \mathrm{C}$, cryolite does not change its composition. Above $500{ }^{\circ} \mathrm{C}$, a second-order phase transition occurs in its crystal structure, which consists in a change in the orientation of the $\mathrm{AlF}_{6}$ octahedra along the $\mathrm{c}$ axis. The restructuring is completed by the high-temperature $\beta$-form of cryolite. At temperatures above $700{ }^{\circ} \mathrm{C}$ in the presence of $\mathrm{KF}$ or an elpasolite phase in the system, the process of dissolution or equalization of $\mathrm{KF}$ concentration occurs according to the diffusion mechanism. Ultimately, a continuous region of solid solution appears in the system based on the elpasolite structure. Upon rapid cooling, $\beta$-cryolite transforms into $\alpha$ cryolite, the solid solution decomposes into $\alpha$-cryolite and a solid solution based on elpasolite with an excess of sodium content of about $2 \%$. With the addition of $\mathrm{LiF}$, sodium in the elpasolite structure is gradually replaced by lithium with the formation, ultimately, of the $\mathrm{K}_{2} \mathrm{LiAlF}_{6}$ phase with the lattice parameter a $=8.0779 \AA$. Dissolution of $\mathrm{LiF}$ in the structure of cryolite $\mathrm{Na}_{3} \mathrm{AlF}_{6}$ was not detected.

\section{Interaction of chiolite with $\mathrm{LiF}$}

Chiolite $\mathrm{Na}_{5} \mathrm{Al}_{3} \mathrm{~F}_{14}$ is the main component in cold sample of acidic electrolyte. It is likely that chiolite should be active with respect to the «basic» additives of the LiF type introduced into the electrolyte. Two variants of interaction of chiolite with $\mathrm{LiF}$ can be assumed. The first is the formation of a chiolite-based solid solution. The second is the interaction with $\mathrm{LiF}$ and the formation of new 


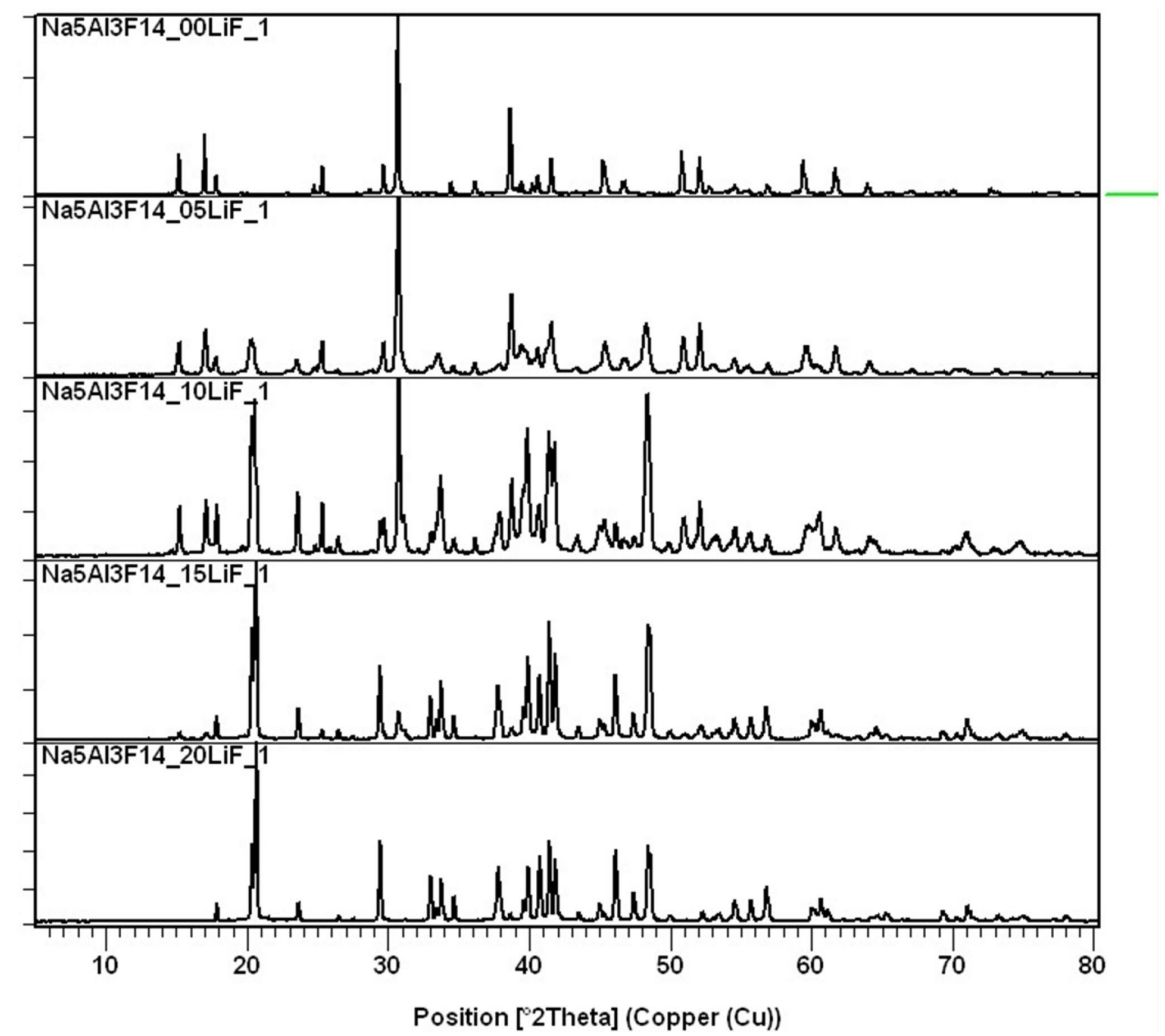

Fig. 4. X-ray powder diffraction patterns of the products of $\mathrm{Na}_{5} \mathrm{Al}_{3} \mathrm{~F}_{14}+5,10,15,20 \mathrm{wt} \% \mathrm{LiF}$ interaction. Chiolite reacted with $\mathrm{LiF}$ to form new phases

phases. The formation of a solid solution based on chiolite was previously observed when part of sodium was replaced by potassium [18, 19]. Refinement of the crystal structure using X-ray powder diffraction data showed that the substitution of sodium for potassium occurs only in the 2-fold position of sodium by $\sim 40 \%$. The limiting dissolution does not exceed $5 \%$ (wt.) KF. The solid solution is stable in the range from melting temperature to room temperature.

To clarify the nature of the interaction, a series of samples of chiolite with LiF was synthesized. Figure 4 shows X-ray diffraction patterns of the synthesis products.

Samples of the series with an increasing amount of LiF have shown that chiolite did not form solid solutions. The interaction even with a small amount of $\mathrm{LiF}$ led to the appearance of the $\mathrm{LiNa}_{2} \mathrm{AlF}_{6}$ phase. It could be observed on the X-ray diffraction patterns that chiolite disappeared (maximum peak at $\left.30.70^{\circ}\right)$, a group of peaks $\left(20-21^{\circ}\right)$, corresponding to $\mathrm{LiNa}_{2} \mathrm{AlF}_{6}$ appeared. «Unreacted» chiolite retained its unit cell parameters. Further increasing $\mathrm{LiF}$ amount, resulted with $\mathrm{LiNa}_{2} \mathrm{AlF}_{6}, \mathrm{Li}_{3} \mathrm{Na}_{(}\left(\mathrm{AlF}_{6}\right)_{2}$ crystallization. When the amount of $\mathrm{LiF}$ is more than $20 \%$ (wt.), $\mathrm{LiNa}_{2} \mathrm{AlF}_{6}, \mathrm{Li}_{3} \mathrm{Na}_{3}\left(\mathrm{AlF}_{6}\right)_{2}$ and traces of $\mathrm{Li}_{3} \mathrm{AlF}_{6}$ were observed in the reaction products.

\section{Conclusion}

Thus, crystallization of $\mathrm{K}_{2} \mathrm{NaAlF}_{6}$ from melted electrolyte in the presence of $\mathrm{LiF}$ in the melt finishes with the formation of a solid solution of the composition $\mathrm{K}_{2} \mathrm{Na}_{1-\mathrm{x}} \mathrm{Li}_{\mathrm{x}} \mathrm{AlF}_{6}$. The boundaries of the 
region of solid solutions allow complete replacement of sodium by lithium. Potassium is not subjected to substitution. $\mathrm{Na}_{5} \mathrm{Al}_{3} \mathrm{~F}_{14}$ during crystallization does not form solid solutions with $\mathrm{LiF}$. $\mathrm{LiNa}_{2} \mathrm{AlF}_{6}$ initially crystallizes from acidic melts $(\mathrm{KO}<2.3)$ in the presence of $\mathrm{LiF}$. At a high concentration of $\mathrm{LiF}$, along with $\mathrm{LiNa}_{2} \mathrm{AlF}_{6}, \mathrm{Li}_{3} \mathrm{Na}_{3}\left(\mathrm{AlF}_{6}\right)_{2}$ and $\mathrm{Li}_{3} \mathrm{AlF}_{6}$ crystallize.

\section{References}

1. Grjotheim, K., Krohn, C., Malinovsky, M., Matiasovsky, K. Aluminium Electrolysis. Fundamentals of the Hall-Heroult Process. 2nd ed. Dusseldorf: Aluminum-Verlag, 1982.

2. Thonstad, J., Fellner, P., Haarberg, G.M. Aluminium Electrolysis Fundamentals of the HallHérout Process. 3nd ed. Dusseldorf: Aluminum-Verlag, 2001.

3. Padamata, S.K., Yasinskiy, A.S., Polyakov, P. V. Electrolytes and its additives used in aluminum reduction cell. A review Metallurgical Research and Technology. 2019. Vol. 116(4). P. 410.

4. Alarie, J., Kiss, L.I., Poncsák, S., Santerre, R., Guérard, S., Bilodeau, J.-F. Influence of Additives on Alumina Dissolution in Superheated Cryolite Melts. Minerals, Metals and Materials. 2021. Vol. 6. P. 533-540.

5. Yang, Yo., Hu, X., Wang, Zh., Yasinskiy, A., Polyakov P., Shi, Zh. Potassium Balance and Its Distribution in Commercial Aluminum Reduction Cells - When Potassium-containing Alumina Is Used as the Raw Material for Aluminum Electrolysis. The Electrochemical Society of Japan. 2020. Vol. 88(6), P. 574-579.

6. Tao, Sh., Peng, J., Di. Yu., Liu, K., Zhao, K., Feng, N. Electrochemical Study of Potassium Fluoride in a Cryolite-Aluminum Oxide Molten Salt. Analytical Letters. 2015. Vol. 48(2). P. 371-381.

7. Hui, G., Jie, L., Hongliang, Zh., Jiawei, L., Jingkun, W., Chunling, M., Shangyuan, W., Chuanxin, Z. Study on micro-structure and transport properties of KF-NaF-AlF3-A12O3 system by first-principles molecular dynamics simulation. J. of Fluorine Chem. 2020. Vol. 235, 109546.

8. Nekrasov, V.N., Limanovskaya, O.V., Suzdal'tsev, A.V., Khramov, A.P., Zaikov Y.P. Stationary anodic process at platinum in KF-NaF-AlF3-Al2O3 melts. Russ. Metall (Metally.) 2014. P. 664-670.

9. Dedyukhin, A., Apisarov, A., Tin'ghaev, P., Redkin, A., Zaikov, Y. Electrical Conductivity of the KF-NaF- AlF3 Molten System at Low Cryolite Ratio with CaF2 Additions. Light Metals. 2011. P. $563-565$.

10. Suzdaltsev A. V., Nikolaev A. Yu., Zaikov Yu.P. Towards the Stability of Low-Temperature Aluminum Electrolysis. J. of The Electrochemical Society. 2021. Vol. 168. 046521.

11. Wang, J.-Q., Li, C.-L., Chai, D.-P., Zhou, Y.-F., Fang, B., Li, Q. Relationship between aluminium electrolysis current efficiency and operating condition in electrolyte containing high concentration of Li and K. Minerals, Metals and Materials Series. 2018. Vol. F4. P. 621-626.

12. Kirik, S.D., Kulikova, N.N., Yakimov, I.S., Klueva, T.I., Baranov, I.A., Buzunov, V.Y., Goloschapov, V.G. Industrial Application of XRD Approach for Electrolyte Control in Domestic Aluminum Production. Nonferrous metals. 1996. Vol. 9. P. 75-77 (in Russ.)

13. Craig, D.F., Brown, J.J. Phase equilibria in the System CaF2-AlF3-Na3AlF6 and Part of the System CaF2-AlF3-Na3AlF6-Al2O3. J. J. Am. Ceram. Soc. 1980. Vol. 63. P. 254-261.

14. Chrenkova, M., Danek, V., Silny, A. In Solid solutions in the system Na3AlF6-CaF2, Ninth International Symposium on Light Metals Production, NTNU Trondheim Norway, Thonstad, J., Ed. NTNU Trondheim, Norway, 1997. 
15. Holm, J.L., Holm, B. J. Phase Investigations in the system Na3AlF6-Li3AlF6. Acta Chem. Scand. 1970. Vol. 24. P. 2535-2546.

16. Stinton, D.P., Brown, J. Phase equilibria in the system Na3A1F6-Li3A1F6. J. Am. Ceram. Soc. 1975. Vol. 58, P. 257.

17. Grjotheim, K., Holm, J.L., Mikhael, S.A. Equilibrium Studies in the Systems. K3AlF6Na3AlF6 and K3A1F6-Rb3AlF6. Acta Chem. Scand. 1973. Vol. 27. P. 1299-1306.

18. Samoilo, A.S., Zaitseva, Y.N., Dubinin, P.S., Piksina, O.E., Ruzhnikov, S.G., Yakimov, I.S., Kirik, S.D. Structural aspects of the formation of solid solutions in the NaF-KF-AlF3 system. $J$. of Solid State Chem. 2017. Vol. 252. P. 1-7.

19. Samoilo, A.S., Zaitseva, Y.N., Dubinin, P.S., Piksina, O.E., Ruzhnikov, S.G., Yakimov, I.S., Kirik, S. D. System NaF-KF-AlF3: Solid Solutions Based on the Chiolite Structure. J. Sib. Fed. Uni/. Chem. 2017. Vol. 10(2). P. 165-174.

20. Rodrigues-Carvajal J. FullProf version 4.06. ILL (unpublished), March 2009.

21. Hawthorne, F.C., Ferguson, R. B. Refinement of the crystal structure of cryolite. The Canadian Mineralogist. 1975. Vol. 13(4). P. 277-282. 